\title{
PHYSICAL ACTIVITY ASSESSMENT TOOLS IN MONITORING PHYSICAL ACTIVITY: THE GLOBAL PHYSICAL ACTIVITY QUESTIONNAIRE (GPAQ), THE INTERNATIONAL PHYSICAL ACTIVITY QUESTIONNAIRE (IPAQ) OR ACCELEROMETERS - CHOOSING THE BEST TOOLS
}

\section{NARZĘDZIA BADAWCZE W MONITOROWANIU AKTYWNOŚCI FIZYCZNEJ: GLOBALNY KWESTIONARIUSZ AKTYWNOŚCI FIZYCZNEJ (GPAQ), MIĘDZYNARODOWY KWESTIONARIUSZ AKTYWNOŚCI FIZYCZNEJ (IPAQ) CZY AKCELEROMETRY - JAKI WYBÓR JEST NAJLEPSZY?}

\author{
Marian Stelmach ${ }^{1(\mathrm{~A}, \mathrm{~B}, \mathrm{C}, \mathrm{D}, \mathrm{E}, \mathrm{F}, \mathrm{G})}$
}

\author{
${ }^{1}$ Department of Health and Social Sciences, \\ Pope John Paul II State School of Higher Education in Biala Podlaska, Poland
}

Authors' contribution Wkład autorów:

A. Study design/planning zaplanowanie badań

B. Data collection/entry zebranie danych

C. Data analysis/statistics dane - analiza i statystyki D. Data interpretation interpretacja danych E. Preparation of manuscript przygotowanie artykułu F. Literature analysis/search wyszukiwanie i analiza literatury G. Funds collection zebranie funduszy

\section{Summary}

Assessing physical activity in epidemiological studies is a severe challenge for researchers, whose overriding aim is to obtain accurate, truthful and reliable data on the level of physical activity in different population groups. Presently, both objective and subjective measurement methods are used. The tools used in objective methods are usually pedometers and accelerometers, while in subjective are used questionnaires conducted and run either as self-reported or by a trained interviewer. At the end of the 1990s, experts in the field of epidemiology of physical activity began developing normalised and standardised tools for subjective assessment of physical activity. After several years of experience, we know that well-chosen and properly validated tools used in the testing process conducted in accordance with recommended standards are a prerequisite for obtaining accurate, truthful and reliable data. Although there are over 90 different questionnaires for physical activity, the two most commonly used are the International Physical Activity Questionnaire (IPAQ) and the Global Physical Activity Questionnaire (GPAQ). On the other hand, objective tools such as pedometers or accelerometers are used more and more frequently in cohort and experimental studies, but also those concerning populations. The article reviews the literature on the criteria of selection and usage of these popular tools. The advantages and disadvantages of each of them and the results of the most important comparative validation studies are discussed.

Keywords: physical activity, population studies, cohort studies, GPAQ, IPAQ, accelerometer

\section{Streszczenie}

Ocena aktywności fizycznej w badaniach epidemiologicznych jest poważnym wyzwaniem dla badaczy. Celem nadrzędnym jest pozyskanie dokładnych, prawdziwych i rzetelnych danych dotyczących poziomu aktywności fizycznej różnych populacji. Obecnie, wykorzystywane są zarówno obiektywne jak i subiektywne metody pomiarowe. Narzędziami w badaniach obiektywnych są najczęściej pedometry oraz akcelerometry, natomiast w subiektywnych różnego rodzaju kwestionariusze prowadzone samodzielnie lub przez przeszkolonego ankietera. Pod koniec lat 90. XX wieku, eksperci zajmujący się epidemiologią aktywności fizycznej rozpoczęli opracowywanie znormalizowanych i wystandaryzowanych narzędzi do subiektywnej oceny wysiłków fizycznych. Po kilkunastu latach doświadczeń wiemy, że dobrze dobrane i prawidłowo zwalidowane narzędzia oraz przeprowadzenie procesu badawczego zgodnie z zalecanymi standardami, jest niezbędnym warunkiem do pozyskania dokładnych, prawdziwych i rzetelnych danych. Chociaż istnieje ponad 90 różnych kwestionariuszy aktywności fizycznej, najczęściej wykorzystywane są dwa: Międzynarodowy Kwestionariusz Aktywności Fizycznej (IPAQ) oraz Globalny Kwestionariusz Aktywności Fizycznej (GPAQ). W badaniach kohortowych i eksperymentalnych ale także coraz częściej w badaniach populacyjnych są wykorzystywane narzędzia obiektywne w postaci pedometrów lub akcelerometrów. W artykule dokonano przeglądu piśmiennictwa na temat kryteriów wyboru i zasad korzystania z tych popularnych narzędzi. Omówiono zalety i wady każdego z nich oraz zamieszczono wyniki najważniejszych porównawczych badań walidacyjnych.

Słowa kluczowe: aktywność fizyczna, badania populacyjne, badania kohortowe, GPAQ, IPAQ, akcelerometr
Figures: 0

References: 41

Submitted: 2017 Jun 03

Accepted: 2017 Jul 27

Stelmach M. Physical activity assessment tools in monitoring physical activity: the Global Physical Activity Questionnaire (GPAQ), the International Physical Activity Questionnaire (IPAQ) or accelerometers - choosing the best tools. Health Prob Civil. 2018; 12(1): 57-63. https://doi.org/10.5114/hpc.2018.74189

Address for correspondence / Adres korespondencyjny: Marian Stelmach, Pope John Paul II State School of Higher Education in Biala Podlaska, Sidorska 95/97, 21-500 Biała Podlaska, Poland, e-mail: marian.stelmach@me.com, phone: +48 833449902

Copyright: (C) Pope John Paul II State School of Higher Education in Biała Podlaska, Marian Stelmach. This is an Open Access journal, all articles are distributed under the terms of the Creative Commons Attribution-NonCommercial-ShareAlike 4.0 International (CC BY-NC-SA 4.0) License (http://creativecommons.org/licenses/ by-nc-sa/4.0/), allowing third parties to copy and redistribute the material in any medium or format and to remix, transform, and build upon the material, provided the original work is properly cited and states its license. 


\section{Introduction}

Physical activity is fundamental to people's life. The human body has evolved over millions of years into a complex organism capable of performing complex motor tasks using both big and small muscle groups. Walking, jogging, throwing or picking up different items are activities that involve most muscles. In the past, as hunter-gatherers, people had to travel long distances to find food or avoid being attacked by wild animals. As food was difficult to obtain, the human body had to adopt energy-saving behaviours. Despite the development of civilisation, body's movement was still used in agriculture, construction, transport as well as in the army and sports.

Nowadays, many forms of motor activity have been neglected in everyday life. The widespread impression that there are many active people who perform various sports and support leisure forms (running, cycling, Nordic Walking or downhill skiing) is misleading as most persons are not involved in physical activity. In the population dimension, there is a systematic decline in the level of physical activity (daily or weekly energy expenditure associated with physical activity). It seems that increasing knowledge in this area of human activity is not fully utilised to explain adverse changes [1].

It is commonly accepted that regular physical activity (PA) is one of the most effective prevention of chronic non-communicable diseases (NCDs) such as type II diabetes, stroke, hypertension, obesity or ischemic heart disease. There is much scientific evidence from systematic screening studies that shows the relationship between low levels of physical activity and increased mortality due to the above causes. Further, it has been proven beyond doubt that there is a direct link between physical activity and cardiovascular health; reduction of the risk of coronary heart disease (CHD) and other cardiovascular diseases (CVD) such as a stroke or hypertension. A systematic physical effort improves circulatory-respiratory fitness, which is directly influenced by its intensity, frequency and duration. There exists a significant positive relationship between a daily dose of physical activity and the development of CVD and CHD [2-6].

The level of 150 minutes of moderate-intensity effort a week can lead to a reduction of the risk of getting ill. There is also a direct link between physical activity and metabolic health, including a lower risk of developing type II diabetes and metabolic syndrome [7]. The data indicate that the implementation of the above-presented level of physical activity significantly reduces the risk of the mentioned diseases. Besides, positive dependency is noted between the volume of aerobic exercise and maintaining normal body weight. Accumulation of energy expenditure related to the undertaken efforts is an essential element of energy balance. It turns out that the sum of energy expenditure that can be achieved by performing a short, at least a 10 minute, exercise session has the same effect in this regard as one long effort. The evidence for the beneficial effects of physical exercise in this context is less consistent than in the case of resistance training, which is partly due to an equalising increase in lean body mass [8]. The relationship between the level of physical activity and maintaining a proper weight is dependent on a considerable inter-personal variability.

In order to maintain healthy body weight, it is necessary to increase the weekly energy expenditure. The data from 12-month randomised controlled examinations indicate that an aerobic exercise for at least 150 minutes per week leads to a weight loss of around 1-3\% [9]. This result is sufficient to maintain proper values for one's age and height. Besides, active people gain bone mineral density, thereby reducing the risk of bone fracture (especially a hip fracture) and spinal injuries. A more extensive amount of exercise training aggregates skeletal muscle mass, strength and body neuromuscular activation [10]. Regular physical activity is also associated with the prevention of cancer, mainly colon cancer. The data show that moderate to high-intensity physical activity, performed for at least 45-60 minutes per day, is necessary to achieve a significant reduction in the risk of developing malignant neoplasms [11]. In general, much of the so-called hard evidence indicates that lower mortality rates caused by coronary heart disease, high blood pressure, stroke, type II diabetes, metabolic syndrome, colon cancer, breast cancer or even depression are visible in more active individuals than the less active ones. There is also substantial evidence that active persons exhibit higher levels of circulatory-respiratory and muscle performance. They are more likely to have regular body weight and "healthier" tissue composition than the physically inactive ones [12].

Taking all of the above facts into consideration, the World Health Organization (WHO) has developed guidelines stating that adults who wish to maintain or improve health should do at least 150 minutes of aerobic physical exercise of a moderate or high-intensity level, or respectively 75 minutes of moderate or intense aerobic physical exercise per week. In order to achieve the recommended amount of minimum activity (WHO), it is essential to do the work in cycles lasting at least 10 minutes. These recommendations are even more restrictive for children and adolescents. And so, children and adolescents aged 5-17 should do intensive and moderate-intensity physical exercise for no less than 60 minutes per day (the total time). Exceeding the above recommended 60-minute activity provides many additional health benefits. Similarly as in adults, children and adolescents should do 
most of their daily exercise in the form of aerobic endeavours. In the case of children, it is crucial to involve them in intensive efforts as often as possible, including those that strengthen muscles and bones [13].

Monitoring and assessing the level of physical activity of entire populations, as well as different social cohorts are processes aimed at determining the variability of the studied phenomena, which in turn enables implementation of corrective measures early enough as well as measuring the effectiveness and efficiency of the introduced programmes [14]. Regardless of the chosen means (methods, tools), monitoring physical activity should constitute an important part of the assessment of implementation and effects of the WHO strategies concerning global diet, physical activity and health. In line with its own government's commitment to the WHO guidelines, each country should seriously engage in physical activity control. Implementation of the surveillance will allow for periodic evaluation of the effectiveness of programmes and policies at the national level and an increase of physical activity at the population level; thereby reducing the risk of developing NCDs [15].

\section{Significance of the research tools in measuring physical activity}

The study of health behaviours, including physical activity, both in young people and adults, is essential for effective public health action. In 2008, Guthold et al. [16] conducted the most extensive cross-sectional physical activity survey covering representative populations of all geographical WHO regions. The study involved 259 526 people from 51 countries. It used the International Physical Activity Questionnaire (IPAQ) - short form. Before, such a massive comparable cross-sectional study conducted internationally had been done only in regard to smoking and the incidence of obesity. As far as physical activity was concerned, there were no adequate monitoring systems. The IPAQ questionnaire, developed for the use in population-based health-promoting physical activity (HEPA) surveys, was the first one that enabled such a large project.

The Global Physical Activity Questionnaire (GPAQ) was developed as part of the WHO Global Programme on Risk Factors (STEPS) in 2002. The STEPS programme was introduced to monitor 8 key non-communicable chronic disease risk factors (NCDs), particularly in developing countries. [17] The GPAQ questionnaire is optimised when compared with the IPAQ-S and IPAQ-L questionnaires as it is a tool used for measuring physical activity on a population scale. The results of validation studies show that the GPAQ fulfils both repeatability and accuracy criteria compared to other instruments used in subjective research methods [18]. The authors of the questionnaire encourage researchers to use the tool especially in countries with lower levels of economic development and high social differentiation, the more that there are several areas in which further useful work could be done. For example, it seems desirable to conduct further GPAQ tests in some countries in order to build a more comprehensive evidence base that could be used internationally, particularly in the Eastern Mediterranean and European regions [19].

Physical activity monitoring systems using the IPAQ and GPAQ questionnaires have become very common. Increasingly, more advanced tools, i.e. electronic monitors - accelerometers, are employed to oversee physical activity especially in the most economically developed countries in the world [20-23]. Perhaps in the next few years, this technology will become cheaper and more accessible, which would enable conducting extensive national and international observations over the next few years.

The implementation of the Global Strategy for Diet, Physical Activity and Health (DPAS) [24] has resulted in a significant demand for internationally comparable physical activity data that could be used in quantification of health threats and trends surveillance within countries. Being familiar with commonly used tools in the world's research is vital for proper preparation of research projects whose results would be of interest to other researchers. Our review of the literature on the issue discusses problems related to the most commonly used methods of physical activity surveillance. Thus, it could be helpful for all those who wish to be informed about the existing methods, techniques and research tools in their proper choices.

\section{Subjective methods for evaluating physical activity}

The work of expert teams trying to develop the first normalised physical activity questionnaire began around 1998, along with the development of the IPAQ. The goal was to construct a comprehensive measuring tool for assessing energy expenditure that would be related to physical effort in different areas of people's everyday life.

\section{International Physical Activity Questionnaire (IPAQ)}

The construction of the questionnaire enables its adaptation to a wide range of languages and cultures. The reliability and usefulness of this population survey questionnaire were validated in 12 countries already in 2003 , 
and the results demonstrated acceptable measurement properties [25]. The short form (IPAQ-S) can be used in population and cohort studies to monitor health risks and to assess the level of physical activity. This version consists of 7 questions concerning a week time dimension, in which moderate and high-intensity efforts are performed as well as walking and sitting. The data obtained from the IPAQ-S questionnaire enable classifying a population into three groups: inactive, moderately active and very active. Researchers can complete the study using two techniques - a self-administered one or a telephone interview [26].

Since 2005, researchers have also had access to a long form of IPAQ-L, which is used as a normalised tool for estimating the physical activity in populations from different countries and socio-cultural circles, which allows for an assessment of energy expenditure for each domain of activity (PA domains). The IPAQ-L is designed for a comprehensive evaluation of everyday moderate or intense physical activity in such domains as job-related activity, transportation, housework, sport and recreation, and sedentary behaviour. It enables monitoring physical activity in population and cohort studies of people aged 15 to 69 years. This version is most often used as an evaluation tool in interventional studies of different cohorts, such as people with diabetes, cancer, arthritis or arthritis in the elderly [27-29]. The IPAQ - long form is also used in large physical activity research, which intends to obtain detailed information on frequency, intensity and place of the reported activity. However, the construction of this form of the questionnaire does not allow to conduct a study in teenagers, especially under 15 years of age. Therefore, a modified version of IPAQ-A was developed and used in testing European teenagers aged 12-17 in the HELENA study [30].

\section{Global Physical Activity Questionnaire (GPAQ)}

The Global Physical Activity Questionnaire (GPAQ) has been developed as an intermediate tool for both versions of IPAQ, and it is supposed to minimise differences in the assessment of physical activity between different countries. This questionnaire takes advantage of all good solutions used in IPAQ-S and IPAQ-L but avoids interpretative discrepancies that appear when the IPAQ questionnaire is used. The goal of the GPAQ was to provide a tool that would provide credible and reliable results from population-based physical activity surveys, especially in developing countries where behavioural patterns differ from those in highly developed countries. An initial validation and qualitative studies were conducted in nine countries, and their results were satisfactory [19]. The Global Observatory for Physical Activity Steering Committee together with the WHO and the US Centres for Disease Control and Prevention introduced minor changes when in the final version of GPAQv2. The GPAQ assesses physical activity in all domains of life (work, transport or leisure). Currently, it is used by over 100 countries as the GPAQ has become the most common tool in diagnostic and evaluation studies of physical activity, especially in developing countries [31].

The reliability and sureness of the GPAQ were initially assessed using pedometers and accelerometers under a survey conducted in nine countries [19]. The chiropractic verification showed a moderate correlation coefficient (Spearman $\rho=0.35$ ) with total physical activity. The validation of the GPAQ carried out in a similar way in other countries such as China, Ethiopia, Indonesia and Japan also showed significant but mild to moderate correlations, and the Spearman coefficient $\rho$ ranged from 0.23 to 0.35 for the total level of physical activity. The accelerometer-based validation of the GPAQ was performed in China and South Africa. It showed mild to moderate correlation coefficients (0.23-0.40) for sedentary activity, and a significant correlation coefficient ( 0.26$)$ for moderate to vigorous activity (MVPA) [32]. Further validation studies using accelerometers were conducted in Malaysia, South America, the United States and Europe [18,33,34]. Using the GPAQ has several advantages as the questionnaire focuses mainly on three general domains of one's activity involving efforts made at work while being active and while resting. These features increase its applicability compared to the IPAQ questionnaire. In addition, the GPAQ is also concise - it contains 16 questions (11 fewer when compared to 27 items in the IPAQ-L). Besides, it is standardised so that it can be used in international research regardless of a geographic region and socio-cultural and economic characteristics of the population.

The GPAQ was designed for face-to-face interviews conducted by trained interviewers. Further, sample "socially-populated" demonstration cards were developed for each of the activities indicated in the GPAQ, including intensive and moderate activity at work, transport activity, leisure activities as well as sitting. Demonstration cards are prepared so as to help respondents better understand the activity meant by the pollster. The development of such cards for a particular population should take into account the local features of the surveyed population [35]. Although the GPAQ is highly credible and widely used for international comparisons, it can cause problems in some populations or cohorts connected with atypical and heterogeneous forms of physical activity [36]. 


\section{Objective methods for evaluating physical activity: pedometer and accelerometer}

Exact measurements of the level of physical activity in a population are essential for assessing the effectiveness of interventions aimed at changing people's behaviour in reducing sedentarism and advocating an active lifestyle. In the case of cardiovascular disease, type II diabetes or multi-cause mortality, increasing the weekly physical activity to a minimum of half an hour in at least 5 days a week brings measurable benefits [13]. This means that the highest risk of becoming ill concerns the most inactive people. Therefore, it seems sensible to focus on interventions in these cohorts that represent the lowest levels of physical activity. Although selfreporting of physical activity by means of questionnaires is widely used, mainly because of the low cost, ease of implementation and low burden on participants, this method of doing research has significant limitations in estimating accurate data. Self-evaluation tends to show an overestimation of the actual physical activity [37].

Some large population studies have used objective tools, i.e. pedometers and accelerometers, for several years. Pedometers record steps, while accelerometers are very advanced electronic devices that record all movements performed by the person while estimating intensity, duration and energy expenditure. Pedometers seem a better and more accessible choice in large observational and intervention studies because of low cost and immediate feedback. However, in estimating energy consumption, pedometers lack accuracy, and the error rate is high $(30 \%$ or more vs. $2.5 \%)$ compared to accelerometers [38,39]. Currently, accelerometers are the most modern method of objective physical activity surveillance and, at the same time, a standard method of evaluating the reliability of physical activity questionnaires [40]. The use of accelerometers in large studies is costly, but researchers are increasingly turning to them in population studies [41].

\section{Conclusions}

Lack of physical activity (physical inactivity) contributes to the development of chronic non-communicable diseases, especially in rich countries, which is also increasingly true of low- and middle-income countries. Understanding why people are more or less physically active may help to conduct interventions based on hard scientific data. These data should be gained from reliable research. Over the last decades, knowledge on the determinants of physical activity in societies has increased significantly. Also, ecological models determining physical activity have been developed basing on a wide range of causes influencing people's health. Besides, new research areas have been identified in which determinants of an active lifestyle are going to be surveyed. Knowledge of these determinants, especially in low- and middle-income countries, could reduce the upward trend in civilisation diseases. Such research should however be based on the most advanced and widely used tools in the world.

\section{References:}

1. Thomas JR, Silverman SJ, Nelson JK. Research Methods in Physical Activity. Human Kinetics; 2010.

2. Steyn K, Sliwa K, Hawken S, Commerford P, Onen C, Damasceno A, et al. Risk factors associated with myocardial infarction in Africa: the INTERHEART Africa study. Circulation. 2005: 112 (23): 3554-3561. https://doi.org/10.1161/CIRCULATIONAHA.105.563452

3. Oja P, Kelly P, Pedišić Ž, Titze S, Bauman A, Foster C, et al. Associations of specific types of sports and exercise with all-cause and cardiovascular-disease mortality: a cohort study of 80306 British adults. British Journal of Sports Medicine. 2017: 51(10): 812-817. https://doi.org/10.1136/bjsports-2016-096822

4. Nocon M, Hiemann T, ller-Riemenschneider FM, Thalau F, Roll S, Willich SN. Association of physical activity with all-cause and cardiovascular mortality: a systematic review and meta-analysis. European Journal of Cardiovascular Prevention \& Rehabilitation. 2008: 15(3): 239-246. https://doi.org/10.1097/HJR.0b013e3282f55e09

5. Samitz G, Egger M, Zwahlen M. Domains of physical activity and all-cause mortality: systematic review and dose-response meta-analysis of cohort studies. International Journal of Epidemiology. 2011: 40(5): 13821400. https://doi.org/10.1093/ije/dyr112

6. Berlin JA, Colditz GA. A meta-analysis of physical activity in the prevention of coronary heart disease. American Journal of Epidemiology. 1990; 132(4): 612-28.

https://doi.org/10.1093/oxfordjournals.aje.a115704

7. Cook S, Auinger P, Li C, Ford ES. Metabolic syndrome rates in United States adolescents, from the NationalHealth and Nutrition Examination Survey,1999-2002.The Journal of Pediatrics.2008; 152(2): 16570. https://doi.org/10.1016/j.jpeds.2007.06.004 
8. Saris WHM, Blair SN, van Baak MA, Eaton SB, Davies PSW, Di Pietro L, et al. How much physical activity is enough to prevent unhealthy weight gain? Outcome of the IASO 1st Stock Conference and consensus statement. Obesity reviews : an official journal of the International Association for the Study of Obesity. 2003; 4(2): 101-14. https://doi.org/10.1046/j.1467-789X.2003.00101.X

9. Physical Activity Guidelines Advisory Committee Report, 2008. To the Secretary of Health and Human Services. Part A: executive summary. Nutrition rewiews. 2009; 67(2): 114-20. https://doi.org/10.1111/j.1753-4887.2008.00136.x

10. Steffl M, Bohannon RW, Sontakova L, Tufano JJ, Shiells K, Holmerova I. Relationship between sarcopenia and physical activity in older people: a systematic review and meta-analysis. Clinical Interventions in Aging. 2017; 12: 835-45. https://doi.org/10.2147/CIA.S132940

11. Friedenreich CM, Orenstein MR. Physical activity and cancer prevention: etiologic evidence and biological mechanisms. Journal of Nutrition. 2002; 132(11): 3456-64.

12. Touvier M, Kesse-Guyot E, Méjean C, Pollet C, Malon A, Castetbon K, et al. Comparison between an interactive web-based self-administered $24 \mathrm{~h}$ dietary record and an interview by a dietitian for large-scale epidemiological studies. British Journal of Nutrition. 2011; 105(7): $1055-64$. https://doi.org/10.1017/S0007114510004617

13. World Health Organization. Global recommendations on physical activity for health. 2011

14. World Health Organization. Global Strategy on Diet, Physical Activity and Health: a framework to monitor and evaluate implementation. 2006.

15. World Health Organization. Diet, nutrition and the prevention of chronic diseases: report of a joint WHO/ FAO expert consultation. 2003.

16. Guthold R, Ono T, Strong KL, Chatterji S, Morabia A. Worldwide Variability in Physical Inactivity. American Journal of Preventive Medicine. 2008; 34(6): 486-94. https://doi.org/10.1016/j.amepre.2008.02.013

17. Armstrong T, Bonita R. Capacity building for an integrated noncommunicable disease risk factor surveillance system in developing countries. Ethnicity \& Disease. 2003; 13(2)

18. Cleland CL, Hunter RF, Kee F, Cupples ME, Sallis JF, Tully MA. Validity of the Global Physical Activity Questionnaire (GPAQ) in assessing levels and change in moderate-vigorous physical activity and sedentary behaviour. BMC public health. 2014; 14(1): 92. https://doi.org/10.1186/1471-2458-14-1255

19. Bull FC, Armstrong T, Maslin TS. Global physical activity questionnaire (GPAQ): nine country reliability and validity study. Journal of Physical Activity \& Health. 2009; 6(6): 790-804.

20. Van Dyck D, Cardon G, Deforche B, Giles-Corti B, Sallis JF, Owen N, et al. Environmental and Psychosocial Correlates of Accelerometer-Assessed and Self-Reported Physical Activity in Belgian Adults. International Journal of Behavioral Medicine. 2011; 18(3): 235-45. https://doi.org/10.1007/s12529-010-9127-4

21. Tudor-Locke C, Mire EF, Dentro KN, Barreira TV, Schuna JM, Zhao P, et al. A model for presenting accelerometer paradata in large studies: ISCOLE. International Journal of Behavioral Nutrition and Physical Activity. 2015; 12(1): 52. https://doi.org/10.1186/s12966-015-0213-5

22. Berkemeyer K, Wijndaele K, White T, Cooper AJ, Luben R, Westgate K, et al. The descriptive epidemiology of accelerometer-measured physical activity in older adults. International Journal of Behavioral Nutrition and Physical Activity. 2016; 13(1): 2. https://doi.org/10.1186/s12966-015-0316-z

23. Kim Y, Hibbing P, Saint-Maurice PF, Ellingson LD, Hennessy E, Wolff-Hughes DL, et al. Surveillance of Youth Physical Activity and Sedentary Behavior With Wrist Accelerometry. American Journal of Preventive Medicine. 2017; 52(6): 872-9. https://doi.org/10.1016/j.amepre.2017.01.012

24. Assembly WHO. Global Strategy on Diet, Physical Activity and Health. 2004; 1-18.

25. Craig CL, Marshall AL, Sjostrom M, Bauman AE, Booth ML, Ainsworth BE, et al. International physical activity questionnaire: 12-country reliability and validity. Medicine and Science in Sports and Exercise. 2003; 35(8): 1381-95. https://doi.org/10.1249/01.MSS.0000078924.61453.FB

26. Bauman AE, Sallis JF. Global Problems Require Global Studies. American Journal of Preventive Medicine. 2008; 34(6): 544-5. https://doi.org/10.1016/j.amepre.2008.03.001

27. Tomioka K, Iwamoto J, Saeki K, Okamoto N. Reliability and Validity of the International Physical Activity Questionnaire (IPAQ) in Elderly Adults:The Fujiwara-kyo Study. Journal of Epidemiology. 2011; 21(6): 45965. https://doi.org/10.2188/jea.JE20110003

28. Crinière L, Lhommet C, Caille A, Giraudeau B, Lecomte P, Couet C, et al. Reproducibility and Validity of the French Version of the Long International Physical Activity Questionnaire in Patients with Type 2 Diabetes. Journal of Physical Activity \& Health [Internet]. 2011; 8(6): 858-65. https://doi.org/10.1123/jpah.8.6.858

29. Bertheussen GF, Oldervoll L, Kaasa S, Sandmæl J-A, Helbostad JL. Measurement of physical activity in cancer survivors - a comparison of the HUNT 1 Physical Activity Questionnaire (HUNT 1 PA-Q) with the 
International Physical Activity Questionnaire (IPAQ) and aerobic capacity. Supportive Care in Cancer. 2013; 21(2): 449-58. https://doi.org/10.1007/s00520-012-1530-8

30. Hagströmer M, Bergman P, De Bourdeaudhuij I, Ortega FB, Ruiz JR, Manios Y, et al. Concurrent validity of a modified version of the International Physical Activity Questionnaire (IPAQ-A) in European adolescents: The HELENA Study. International journal of obesity. 2008; 32 Suppl 5: S42. https://doi.org/10.1038/ijo.2008.182

31. Armstrong T, Bull F. Development of the World Health Organization Global Physical Activity Questionnaire (GPAQ). Journal of Public Health. 2006; 14(2): 66-70. https://doi.org/10.1007/s10389-006-0024-X

32. Mathews E, Salvo D, Sarma PS, Thankappan KR, PRATT M. Adapting and Validating the Global Physical Activity Questionnaire (GPAQ) for Trivandrum, India. 2013. Preventing chronic disease. 2016; 13(4): 150528. https://doi.org/10.5888/pcd13.150528

33. Herrmann SD, Heumann KJ, Ananian CA Der, AINSWORTH BE. Validity and Reliability of the Global Physical Activity Questionnaire (GPAQ). Measurement in Physical Education and Exercise Science. 2013; 17(3): 221-35. https://doi.org/10.1080/1091367X.2013.805139

34. Hoos T, Espinoza N, Marshall SJ, Arredondo EM. Validity of the Global Physical Activity Questionnaire (GPAQ) in adult Latinas. Journal of Physical Activity \& Health. 2012;9(5):698-705.

35. World Health Organization. Global Physical Activity Questionnaire (GPAQ). 2006.

36. Anjana RM, Sudha V, Lakshmipriya N, Subhashini S, Pradeepa R, Geetha L, et al. Reliability and validity of a new physical activity questionnaire for India. International Journal of Behavioral Nutrition and Physical Activity. 2015; 12(1): 40. https://doi.org/10.1186/s12966-015-0196-2

37. Wasilewska M. In search of the assessment of the physical activity level of the youth with the use of the IPAQ. Health Problems of Civilization. 2017; 1: 15-22. https://doi.org/10.5114/hpc.2017.65524

38. Crouter SE, Horton M, Bassett DR., Validity of ActiGraph Child-Specific Equations during Various Physical Activities. Medicine and Science in Sports and Exercise. 2013; 45(7): 1403-9. https://doi.org/10.1249/MSS.0b013e318285f03b

39. Calabró MA, Lee JM, Saint-Maurice PF, Yoo H, Welk GJ. Validity of physical activity monitors for assessing lower intensity activity in adults. International Journal of Behavioral Nutrition and Physical Activity. 2014; 11(1): 119. https://doi.org/10.1186/s12966-014-0119-7

40. Van Poppel MNM, Chinapaw MJM, Mokkink LB, Van Mechelen W, Terwee CB. Physical activity questionnaires for adults: a systematic review of measurement properties. Sports medicine (Auckland, NZ). 2010; 40(7): 565-600. https://doi.org/10.2165/11531930-000000000-00000

41. Misra P, Upadhyay RP, Krishnan A, Sharma N, Kapoor SK. A community based study to test the reliability and validity of physical activity measurement techniques. International Journal of Preventive Medicine. 2014 Aug 1; 5(8): 952-9. 